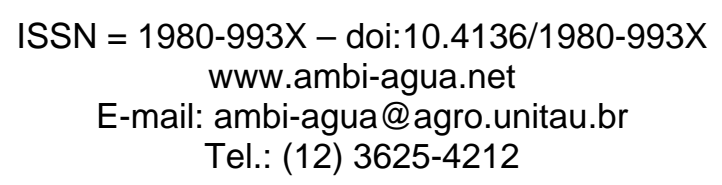

\title{
Trace element residues in water, sediments, and organs of Savacu (Nycticorax nycticorax) from Sepetiba Bay, Rio de Janeiro, Brazil (doi:10.4136/ambi-agua.116)
}

\author{
Aldo Pacheco Ferreira; Marco Aurélio P. Horta \\ National School of Public Health \\ E-mail: \{aldoferreira, mhorta\}@ensp.fiocruz.br
}

\begin{abstract}
Heavy metal $(\mathrm{Cr}, \mathrm{Cd}, \mathrm{Zn}, \mathrm{Cu}, \mathrm{Ni}, \mathrm{Pb})$ concentrations in water, sediment and organs of Savacu, Nycticorax nycticorax were analyzed. Samples of water and sediment were collected from seven stations along Sepetiba Bay, and experimental animals, also were collected in the study area. This bay receives effluents discharges from heavily industrialized and highly populated settlements. Samples of water, sediment and Savacu were processed and analyzed for heavy metals and the results showed that these concentrations in sediment were higher than in water. The exposure to metals either in the water or by the effect of bioaccumulation in the food chain is reflected in the results obtained with animals' test.
\end{abstract}

Keywords: Heavy metals; concentration; seabird; pollution.

\section{Resíduos de elementos-traço na água, sedimentos e em órgãos de Savacu (Nycticorax nycticorax) da Baia de Sepetiba, Rio de Janeiro, Brasil}

\section{RESUMO}

Concentrações de metais pesados $(\mathrm{Cr}, \mathrm{Cd}, \mathrm{Zn}, \mathrm{Cu}, \mathrm{Ni}, \mathrm{Pb})$ foram analisadas na água, sedimentos e órgãos de Savacu (Nycticorax nycticorax). As amostras de água e sedimentos foram coletadas em sete estações ao longo da Baía de Sepetiba, e os animais de experimentação também foram coletadas na área de estudo. Essa baía recebe descargas de efluentes de áreas altamente industrializadas e regiões densamente povoadas. Amostras de água, sedimentos e Savacu foram processadas e analisadas para metais pesados e os resultados mostraram que a concentração destes no sedimento foi maior que da água. A exposição aos metais, seja pela água seja por efeito da bioacumulação na cadeia trófica, reflete-se nos resultados obtidos nos animais-teste.

Palavras-chave: metais pesados; concentração; ave marinha; poluição.

\section{INTRODUCTION}

Contamination of aquatic systems is due not only to natural causes, but mainly to human activities, such as the discharge of domestic and industrial sewage, the leaching of pesticides in agricultural areas among others (Förstner and Wittmann, 1981). When coastal and estuarine environments receive effluents, most often without adequate treatment, high levels of heavy metals, organic chemicals and nutrients can be observed in the water or deposited in the sediment, leading to a contamination of whole ecosystems and its inhabiting marine life. In the context of marine waters contamination, the Sepetiba Bay, with its mangroves and estuarine zones is a natural habitat for many species of birds, molluscs, crustaceans and fish (Machado, 1996). 
FERREIRA, A. P.; HORTA, M. A. P. Trace element residues in water, sediments, and organs of Savacu (Nycticorax nycticorax) from Sepetiba Bay, Rio de Janeiro, Brazil. Ambi-Agua, Taubaté, v. 5, n. 1, p. 17-28, 2010. (doi:10.4136/ambi-agua.116)

As an inductive process of water pollution highlight the gradual increase of industrialization and urban expansion enhancing the introduction of undesirable amounts of pollutants in the environment (Moraes and Jordão, 2002). Besides the process of industrial expansion, Sepetiba Bay is subject to other environmental stresses, such as domestic sewage, waste from agricultural activities and activities of sand extraction (Copeland et al., 2003). However, these activities are less important when compared to the potential risks of contamination that are generated by industrial activity, which affects the structure of the ecosystems in the region, impacting marine life and offering risks to the local population which depends on fishing resources as a source of income and food (Coimbra, 2003).

Heavy metals are transported to coastal ecosystems associated with suspended particles, dissolved in the water column or atmospheric deposition (Pereira and Ebecken, 2009). Such compounds have reached the Sepetiba Bay by river transport, and then transported by coastal currents which are deposited and accumulated (Lacerda and Molisani, 2006). In recent years, toxic effects of heavy metals in living organisms, primarily as a result of its continuous anthropogenic mobilization in the environment, have attracted considerable attention worldwide. Metals are common in urban aquatic ecosystems and, unlike most pollutants, are not biodegradable and thus persistent in the environment (Seebaugh et al., 2005, SchmittJansen et al., 2008).

Marine ecosystems are highly complex, dynamic and subject to many internal and external relationships that are feasible to change over time. Pollutants that enter coastal waters and estuarine zones create serious problems that lead to damage of life and marine activities. Investigators point out the use of birds as indicators of environmental conditions because they are particularly sensitive to changes of anthropogenic origin (Bost and Lemaho, 1993). Waterbirds are particularly valuable for environmental monitoring because they are longlived and top trophic level animals in the food chain, consequently they are able to integrate pollutant levels over a broad area by bioaccumulation (Dale and Beyeler, 2001). The Savacu, Nycticorax nycticorax (Linnaeus, 1758) lives in lowland forests, inhabiting preferentially the coastal strip of eastern Brazil (Branco and Fracasso, 2005).

Consequences related to high levels of contamination have been demonstrated in many aquatic birds. The literature shows that the liver and kidney are substrates widely used in the diagnosis of environmental contamination by heavy metals (Furness and Camphuysen, 1997, Diamond and Devlin, 2003). Aquatic organisms can absorb and integrate metals directly or indirectly through the food chain (Kamala-Kannan et al., 2008). The progressive and irreversible accumulation of such compounds in various organs of marine organisms leads to long-term diseases, because of their toxicity, thus endangering the aquatic biota and other organisms in the food webs (Wanless et al., 2005). Essential metals such as zinc play an important role in metabolism, but many others have no apparent essential function, such as aluminum, cadmium and lead. However, both essential and non-essential metals may be toxic when present above certain threshold concentrations. This toxicity varies among organisms and it depends on the physical and chemical properties of each metal and other factors associated to the environment. The disruption of cell membrane integrity, leading to organ failure, is a known effect of heavy metal in the organism (Gadd, 1993). In aquatic environments, organisms may be exposed not only to a single chemical but a mixture of several substances, and this may affect biotic communities and ecological processes in a nonpredictable way (Ross and Birnbaum, 2003).

High levels of trace metals in sediments can be a good indicator of pollution attributed to anthropogenic influences, rather than natural enrichment by geological weathering (Jesus et al, 2004). Such sediments on the other hand, integrate contaminants over time and are in constant flux with the overlying water column. Analysis of heavy metals in sediments allows the detection of pollutants that may even be absent or in low concentrations in the water 
FERREIRA, A. P.; HORTA, M. A. P. Trace element residues in water, sediments, and organs of Savacu (Nycticorax nycticorax) from Sepetiba Bay, Rio de Janeiro, Brazil. Ambi-Agua, Taubaté, v. 5, n. 1, p. 17-28, 2010. (doi:10.4136/ambi-agua.116)

column and their distribution in coastal sediments provides a record of spatial and temporal history of pollution in a particular region or ecosystem (Davies et al., 2006).

Metal accumulation from the water overlying the sediment depends on a number of external environmental factors such as $\mathrm{pH}$, ionic strength, type and concentration of organic and inorganic ligands and the surface available for adsorption caused by the variation of particle size (Davies et al., 2006; Bonai et al., 2009). The concentration of heavy metals in the water column may be relatively low, but may it be relatively high in sediment as a result of the accumulation of pollutants in a long-term observation, since the heavy metals that are discharged into estuarine and coastal waters are associated with particles that are deposited on the bottom (Balkis and Cagatay, 2001).

This study aims to analyze the anthropogenic distribution of heavy metals in the water column and sediment in different seasons to assess the relationship between the levels of metals found and the bio-accumulated metals in Savacu, a representative indicator of regional avifauna, to evaluate a number of key attributes to effective bio-indicators such as: quantitative, simplifying, user driven, policy relevant, scientifically credible, responsive to changes, easily understood, realistic to collect, and susceptible to analysis (Van Strien, 1999). It also aims to obtain and assess levels of heavy metals, allowing a better understanding of the Sepetiba Bay, and provide subsidies to mitigate the possible contamination caused by industrial activities, urbanization without proper planning, and poor sewage disposal.

\section{MATERIAL AND METHODS}

\subsection{Study site}

Sepetiba Bay is located in the State of Rio de Janeiro, Brazil, $\left(22^{\circ} 55^{\prime}\right.$ and $23^{\circ} 05^{\prime} \mathrm{S} / 43^{\circ}$ $40^{\prime}$ and $44^{\circ} 40^{\prime} \mathrm{W}$ ) with an area of $450 \mathrm{~km} 2$. This region present its northern and eastern area limited by the continent, a sandbank vegetation on southern limit, and Ilha Grande Bay on the west. Its greatest length is 42.5 kilometers from east to west and its greatest width is 17.2 kilometers from north to south, with a perimeter of $122 \mathrm{~km}$.

The watershed contributing to Sepetiba Bay has two main sources: the Serra do Mar mountain chain and an extensive area of lowland, crossed by many rivers, consisting of 22 sub-basins. The main rivers within the catchment area of the Sepetiba Bay and its respective average flow are Gandu River, also known as channel of San Francisco $\left(89 \mathrm{~m}^{3} \cdot \mathrm{s}^{-1}\right)$, Guarda River $\left(6.8 \mathrm{~m}^{3} \cdot \mathrm{s}^{-1}\right)$, Ita channel $\left(3.3 \mathrm{~m}^{3} \cdot \mathrm{s}^{-1}\right)$, Piraquê River $\left(2.5 \mathrm{~m}^{3} \cdot \mathrm{s}^{-1}\right)$, Portinho River $\left(8.8 \mathrm{~m}^{3} \cdot \mathrm{s}^{-1}\right)$, Mazomba River $\left(0.5 \mathrm{~m}^{3} \cdot \mathrm{s}^{-1}\right)$ and Cação River $\left(1.1 \mathrm{~m}^{3} \cdot \mathrm{s}^{-1}\right)$. The other rivers are water bodies of smaller basins, with very low flows. Guandu River is the most important contributor of the basin and it's responsible for supplying water to several cities, being the main source of Rio de Janeiro city.

The Sepetiba Bay basin has an estimated population of $1,295,000$ inhabitants, which generate an output of sewage of about $286,900 \mathrm{~m}^{3} /$ day. The majority of the municipalities included in this basin do not have services of solid waste collection and the release is made commonly in landfills, much of which are located on the banks of rivers close to urban areas, resulting in serious environmental degradation. The uncontrolled increase of population without a corresponding expansion of infrastructure and adequate sanitation generates a large volume of domestic and industrial waste and the use, with expressive heavy metals concentration, are sources of pollution to waters in the basin. About 1.7 million inhabitants live in this region concentrated mainly in urban area (Cunha et al., 2006).

\subsection{Sampling}

Sampling stations covered the entire area of Sepetiba Bay and their coordinates were

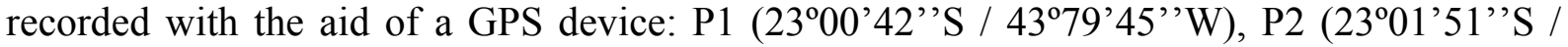

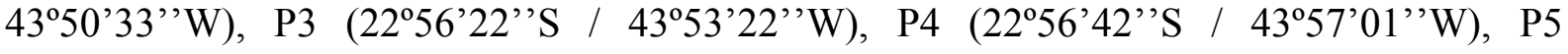


FERREIRA, A. P.; HORTA, M. A. P. Trace element residues in water, sediments, and organs of Savacu (Nycticorax nycticorax) from Sepetiba Bay, Rio de Janeiro, Brazil. Ambi-Agua, Taubaté, v. 5, n. 1, p. 17-28, 2010. (doi:10.4136/ambi-agua.116)

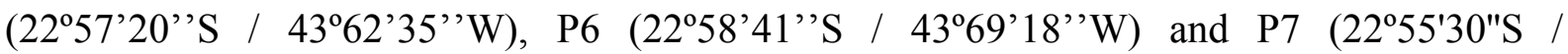
$44^{\circ} 38^{\prime} 03^{\prime \prime W}$ ) (Figure 1). For those seven stations, samples were collected from surface water and sediment in three different seasons, the months of September 2008 (Season 1), December 2008 (Season 2), and May 2009 (Season 3). To assess the quality of water, the following physical and chemical measurements were measured: temperature, $\mathrm{pH}$, dissolved oxygen (DO), electrical conductivity and turbidity. Measurements were recorded with the aid of a probe (HORIBA ${ }^{\circledR}$ mod. U-22 / Water Quality-Checker) calibrated prior to each collection. Physical chemical readings were made at $1.0 \mathrm{~m}$ depth.

A Van Dorn bottle were used to collect water for analysis of metals. The samples were

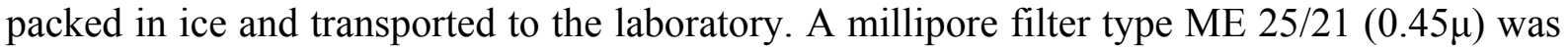
used to filtrate water samples with a vacuum pump. From each sample $100 \mathrm{ml}$ was removed then added $20 \mathrm{ml}$ of nitric acid PA and then the sample was taken to a heating plate to evaporate $60 \mathrm{ml}$ of the solution. After reaching room temperature, $40 \mathrm{ml}$ of $\mathrm{HNO}_{3}$ and $\mathrm{HCl}$ (at a ratio of 1:3 by volume) were added in order to obtain a final solution of $100 \mathrm{ml}$ of sample. For analysis of metals in the sediment samples were collected with Van Veen sampler. Samples were identified, placed in plastic bags and kept refrigerated at $4^{\circ} \mathrm{C}$. In the laboratory the sediments were dried at $60^{\circ} \mathrm{C}$ and then sieved in a mesh of $0.63 \mathrm{~mm}$ (Granutest) to standardize the size and remove shell fragments and larger grains. The samples were freeze dried and stored in sealed plastics protected from heat and light.

Carcasses of Savacu have been collected, identified and stored for later use between 2007 and 2009. Collections have been made in the Coroa Grande mangrove, a traditional nesting site for several species of local avifauna. In this experiment only adult specimens were selected. For analysis of the organs, liver and kidney were obtained, weighed and kept frozen $\left(-20^{\circ} \mathrm{C}\right)$. From each organ $15 \mathrm{~g}$ was prepared and lead to laboratory analysis. The partial concentrations of metals were derived from the digestion of dry samples in $125 \mathrm{ml}$ Erlenmeyer glasses closed with a cold finger containing $20 \mathrm{ml}$ of aqua regia solution $(50 \%)$ in a water bath in the range of $70-80^{\circ} \mathrm{C}$, for 2 hours (Carvalho et al., 2008).

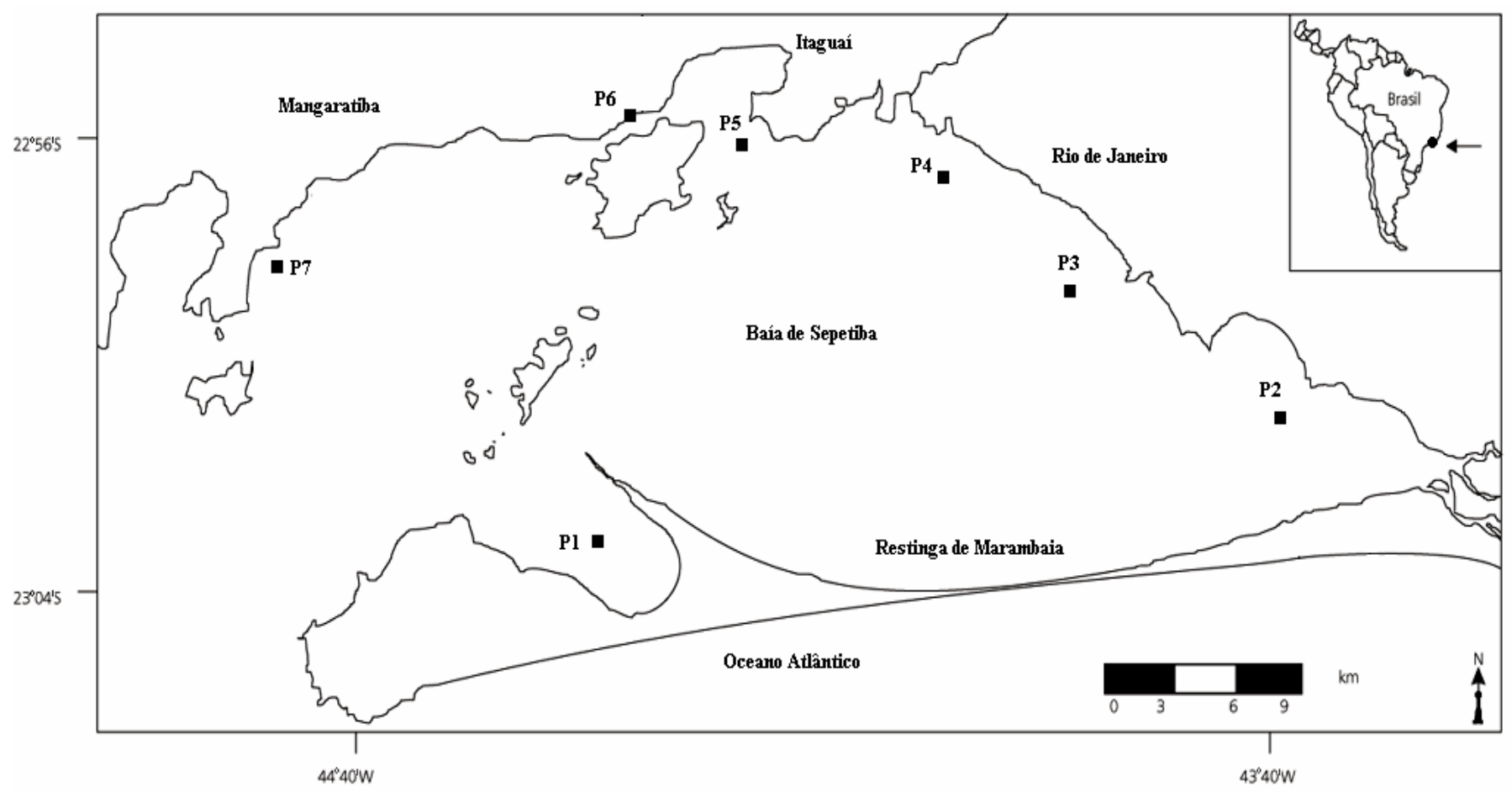

Figure 1. Map of the study area (Sepetiba Bay). P indicates the sampling stations. 
FERREIRA, A. P.; HORTA, M. A. P. Trace element residues in water, sediments, and organs of Savacu (Nycticorax nycticorax) from Sepetiba Bay, Rio de Janeiro, Brazil. Ambi-Agua, Taubaté, v. 5, n. 1, p. 17-28, 2010. (doi:10.4136/ambi-agua.116)

\subsection{Determination of the heavy metal levels in the samples}

The determination of the elements (chromium, copper, nickel, lead, zinc and cadmium) was performed by the method of optical emission spectrometry in inductive plasma (Inductively Coupled Plasma-Optical Emission Spectrometry, ICP) with physical flame of argon. For definition of wavelengths in the ICP, we tested initially, all the possibilities offered by the device, both the axial view and in the radial plane. For each element, the design spectrum of a solution containing only the chemical species was determined in order to identify and adjust the emission peak of the element. The wavelengths of the metals studied were $\mathrm{Cr} 267.716 \mathrm{~nm}, \mathrm{Cu} 324.754 \mathrm{~nm}$, Ni $231.604 \mathrm{~nm}, \mathrm{~Pb} 220.353 \mathrm{~nm}, \mathrm{Zn}$ and Cd $213.856 \mathrm{~nm}$ $226.502 \mathrm{~nm}$. A reading of the blank was made in a sample and the maximum point of the calibration curve in order to investigate possible spectral interferences and, if possible, minimize them, by making adjustments to the baselines, delimiting the peak area. After these adjustments, a reading of the calibration curve was made by selecting the wavelengths that showed the coefficient of determination of the linear model (R2) closer to 1 and with minimal spectral interference. To validate the method, a recovery test of the analytes was used using as reference material the DORM-2, consisting of freeze-dried muscle tissue of fish (dogfish), produced by the National Research Council of Canada (NRCC). The recovery rates of the certified sample were: $\mathrm{Cr}(99 \%), \mathrm{Cu}(87 \%), \mathrm{Ni}(84 \%), \mathrm{Pb}(88 \%), \mathrm{Zn}(102 \%)$ and $\mathrm{Cd}(93 \%)$.

\subsection{Statistical Analysis}

One-way ANOVA was performed to assess differences between the three stations sampled over the values obtained for the concentrations of metals found in water and sediment and the physical and chemical parameters measured. Similarly, a one-way ANOVA was used in order to verify whether there are differences among the seven sampling points in relation to metal content in water and sediment and the physical and chemical parameters. A hierarchical cluster analysis was performed to check the distance between the seven sampling stations in relation to the parameters sampled. The Euclidean distance was used as a method of separation and single linkage as the clustering method. A dendrogram was produced to evaluate the results.

A regression analysis was used to obtain simple linear models with the metal content in the kidney and liver as dependent variables in separate models and metal concentrations in water and sediment in each of the sampling stations as independent variables. The analysis was performed to determine whether there is any relationship between the content of metals in water and sediments and those found in liver and kidney of birds. The KolmogorovSmirnoff test was used to verify the normality of the data. Statistical tests were performed in the package Statistica ${ }^{\circledR} 7.0$.

\section{RESULTS}

Obtained values of conductivity, temperature, $\mathrm{pH}$ and turbidity in water were within the range recommended by CONAMA Resolution No. 357/2005 (Table 1). However, in contrast to the previous parameters, for the data of dissolved oxygen (DO), the points P3, P4 and P5, were in reasonable oxygenation, but moving to reduced levels. P6 station showed slightly within the limits during the period of rain, but had the lowest level in the dry season. Losses of this element occur due to processes of consumption during the oxidation of organic matter, breathing of the organisms and oxidation of metal ions.

For the concentrations of heavy metals in water samples, some values are above the recommended for Class 2 waters, according to Resolution No. 357/2005 (Table 2). Cd contents were satisfactory at stations P1, P6 and P7, and slightly compromised at P2 and above the levels recommended in stations P3, P4 and P5. The levels of Zn were satisfactory at 
FERREIRA, A. P.; HORTA, M. A. P. Trace element residues in water, sediments, and organs of Savacu (Nycticorax nycticorax) from Sepetiba Bay, Rio de Janeiro, Brazil. Ambi-Agua, Taubaté, v. 5, n. 1, p. 17-28, 2010. (doi:10.4136/ambi-agua.116)

stations P1 and P7, and above the levels recommended in stations P2, P3, P4, P5 and P6. The levels of $\mathrm{Cu}$ were satisfactory at stations P1, P2, P3, P6 and P7, and above the levels recommended in the stations $\mathrm{P} 4$ and $\mathrm{P} 5$. The levels of $\mathrm{Pb}$ were satisfactory in all stations. The levels of Cr were satisfactory at stations P1, P2, P3, P6 and P7, and slightly compromised in some samplings in the stations P4 and P5. The levels of Ni were satisfactory at stations P1, P6 and P7, and slightly compromised in some samplings in the stations P2, P3, P4 and P5.

In the sediment, according to Resolution No. 344/2004 (Table 3), the concentrations of Cd showed slightly lower at the P1 and P7, and with higher levels at stations P2, P3, P4, P5, and $\mathrm{P} 6$. The $\mathrm{Cu}, \mathrm{Cr}, \mathrm{Pb}, \mathrm{Ni}$ and $\mathrm{Zn}$ concentrations were in lower levels in all samples.

Table 1. Physical-chemical parameters measured in water at different sampling stations in Sepetiba Bay.

\begin{tabular}{|c|c|c|c|c|c|c|c|c|c|c|c|c|c|c|c|}
\hline \multirow{2}{*}{ Sampling station } & \multicolumn{3}{|c|}{ Condutivity $\left(\mu \mathrm{s} . \mathrm{cm}^{-1}\right)$} & \multicolumn{3}{|c|}{ Temperature $\left({ }^{\circ} \mathrm{C}\right)$} & \multicolumn{3}{|c|}{ Turbidity (UNT) } & \multicolumn{3}{|c|}{ pH } & \multicolumn{3}{|c|}{ OD (mg/L) } \\
\hline & E1 & E2 & $\mathbf{E 3}$ & E1 & E2 & E3 & E1 & E2 & E3 & E1 & $\mathbf{E 2}$ & E3 & E1 & E2 & E3 \\
\hline $\mathrm{P} 1$ & 19,11 & 17,33 & 18,81 & 24,5 & 25,5 & 24,0 & 6,1 & 7,2 & 7,9 & 6,5 & 6,6 & 6,9 & 9,5 & 10,6 & 10,1 \\
\hline $\mathrm{P} 2$ & 15,78 & 17,34 & 19,66 & 25,0 & 26,5 & 25,0 & 9,4 & 7,9 & 8,3 & 7,6 & 7,8 & 7,8 & 7,1 & 7,8 & 6,9 \\
\hline P3 & 17,30 & 17,68 & 11,22 & 24,5 & 27,0 & 25,0 & 12.3 & 13,7 & 16,8 & 8,1 & 8,2 & 7,9 & 4,3 & 5,7 & 5,1 \\
\hline P4 & 16,11 & 17,62 & 10,44 & 25,5 & 27,0 & 25,0 & 16,6 & 15,4 & 16,3 & 8,7 & 8,5 & 8,3 & 4,9 & 5,0 & 4,2 \\
\hline P5 & 17,30 & 17,68 & 16,71 & 25,5 & 26,5 & 25,5 & 16,2 & 14,3 & 13,4 & 8,2 & 8,1 & 7,8 & 4,6 & 4,5 & 4,2 \\
\hline P6 & 17,24 & 18,08 & 12,20 & 26,0 & 26,5 & 25,5 & 15,6 & 15,4 & 16,1 & 7,7 & 7,4 & 7,6 & 6,4 & 5,9 & 4,7 \\
\hline P7 & 18,90 & 17,96 & 15,11 & 24,5 & 25,5 & 24,5 & 8,9 & 9,3 & 10,3 & 6,8 & 6,9 & 6,9 & 7,9 & 8,1 & 8,0 \\
\hline
\end{tabular}

Note: 1) E1-season 1-September 2008/ E2-station 2-December 2008 / E3-season 3-March 2009;

2) Maximum levels - CONAMA 357/2005: Turbidity - up to 100 UNT; pH - 6,5 - 8,5; OD - higher than 6 $\mathrm{mg} / \mathrm{l}$.

Table 2. Heavy metal levels in the waters of Sepetiba Bay $\left(\mu \mathrm{g} . \mathrm{L}^{-1}\right)$.

\begin{tabular}{|c|c|c|c|c|c|c|c|c|c|c|c|c|c|c|c|c|c|c|}
\hline \multirow{2}{*}{$\begin{array}{l}\text { Sampling } \\
\text { Stations }\end{array}$} & \multicolumn{3}{|c|}{ Cd } & \multicolumn{3}{|c|}{$\mathbf{Z n}$} & \multicolumn{3}{|c|}{$\mathbf{C u}$} & \multicolumn{3}{|c|}{$\mathbf{P b}$} & \multicolumn{3}{|c|}{$\mathbf{C r}$} & \multicolumn{3}{|c|}{$\mathrm{Ni}$} \\
\hline & E1 & E2 & E3 & E1 & E2 & E3 & E1 & E2 & E3 & E1 & E2 & $\mathbf{E 3}$ & E1 & E2 & E3 & E1 & E2 & $\mathbf{E 3}$ \\
\hline P1 & 0,1 & - & 0,3 & 140,1 & 108,5 & 82,9 & & 3,6 & 8,2 & 11,2 & 6,7 & 10,1 & - & - & 3,2 & 4,4 & - & 6,7 \\
\hline P2 & 0,8 & 1,2 & 1,4 & 268,5 & 401,2 & 361,5 & 11,5 & 9,7 & 16,6 & 9,3 & 5,6 & 8,9 & 12,3 & 14,5 & 22,4 & 11,2 & 12,3 & 33,6 \\
\hline P3 & 2,1 & 2,2 & 1,8 & 354,5 & 345,4 & 253,4 & 16,3 & 15,7 & 19,5 & 13,4 & 9,6 & 10,4 & 45,4 & 33,3 & 41,2 & 13,5 & 34,3 & 26,4 \\
\hline P4 & 5,7 & 9,8 & 11,3 & 419,2 & 283,4 & 605,9 & 34,5 & 36,4 & 49,6 & 15,5 & 12,3 & 10,2 & 33,4 & 53,2 & 56,3 & 29,8 & 28,6 & 45,3 \\
\hline P5 & 1,5 & 2,4 & 2,6 & 541,1 & 338,7 & 609,6 & 21,0 & 19,6 & 45,8 & 10,1 & 16,1 & 11,6 & 67,8 & 45,6 & 77,1 & 24,5 & 19,9 & 28,0 \\
\hline P6 & 0,5 & 0,6 & 0,7 & 436,0 & 326,7 & 229,2 & 13,3 & 9,8 & 17,6 & 17,2 & 6,5 & 13,3 & 18,9 & 11,2 & 19,5 & 11,1 & 10,3 & 18,3 \\
\hline P7 & 0,2 & 0,2 & 0,4 & 118,8 & 52,8 & 98,2 & 6,5 & 6,2 & 7,3 & 4,2 & 7,7 & 10,9 & 2,4 & 3,8 & 1,2 & 3,3 & 6,6 & 5,5 \\
\hline
\end{tabular}

Note: 1) E1-season 1-September 2008/ E2-station 2-December 2008 / E3-season 3-March 2009;

2) Maximum levels ( $\mu$ g. $\mathrm{L}^{-1}$ ) - CONAMA 357/2005: $\mathrm{Cd}-1, \mathrm{Zn}-180, \mathrm{Cu}-20, \mathrm{~Pb}-30,-50 \mathrm{Cr}, \mathrm{Ni}-25$.

Table 3. Heavy metal levels in sediment of Sepetiba Bay $\left(\mu \mathrm{g} \cdot \mathrm{g}^{-1}\right)$.

\begin{tabular}{|c|c|c|c|c|c|c|c|c|c|c|c|c|c|c|c|c|c|c|}
\hline \multirow{2}{*}{$\begin{array}{l}\text { Sampling } \\
\text { Stations }\end{array}$} & \multicolumn{3}{|c|}{ Cd } & \multicolumn{3}{|c|}{$\mathbf{Z n}$} & \multicolumn{3}{|c|}{$\mathrm{Cu}$} & \multicolumn{3}{|c|}{$\mathbf{P b}$} & \multicolumn{3}{|c|}{$\mathrm{Cr}$} & \multicolumn{3}{|c|}{$\mathbf{N i}$} \\
\hline & E1 & E2 & E3 & E1 & E2 & E3 & E1 & E2 & E3 & E1 & E2 & E3 & E1 & E2 & E3 & E1 & E2 & E3 \\
\hline P1 & 0,031 & 0,042 & 0,092 & 2,32 & 5,12 & 4,43 & 0,005 & 0,005 & 0,121 & 3,41 & 4,34 & 2,33 & 0,34 & 0,45 & 0,67 & 0,033 & 0,041 & 0,009 \\
\hline $\mathrm{P} 2$ & 4,22 & 6,25 & 6,04 & 9,60 & 8,74 & 7,89 & 0,024 & 0,008 & 0,232 & 3,12 & 2,32 & 5,67 & 9,61 & 6,14 & 5,58 & 1,070 & 2,072 & 4,111 \\
\hline P3 & 12,12 & 10,39 & 16,85 & 5,69 & 9,24 & 9,01 & 1,052 & 0,072 & 0,645 & 2,02 & 4,66 & 2,34 & 31,02 & 25,33 & 44,17 & 0,956 & 1,574 & 2,004 \\
\hline $\mathrm{P} 4$ & 16,40 & 22,30 & 45,65 & 11,41 & 7,84 & 11,25 & 1,005 & 0,065 & 0,406 & 19,38 & 17,4 & 35,54 & 24,37 & 22,09 & 24,56 & 2,234 & 3,213 & 5,078 \\
\hline P5 & 14,02 & 9,82 & 18,73 & 19,93 & 18,07 & 33,24 & 1,005 & 0,055 & 0,377 & 6,93 & 5,67 & 42,07 & 20,02 & 18,10 & 20,23 & 4,121 & 8,092 & 7,070 \\
\hline P6 & 2,27 & 2,11 & 5,41 & 8,11 & 8,68 & 16,72 & 2,005 & 1,022 & 0,221 & 15,64 & 24,31 & 31,23 & 5,04 & 9,37 & 12,66 & 1,004 & 5,023 & 3,115 \\
\hline P7 & 0,09 & 0,061 & 1,02 & 3,42 & 2,61 & 3,32 & 0,003 & 2,037 & 0,170 & 0,94 & 0,73 & 1,23 & 1,62 & 2,36 & 3,62 & 0,035 & 0,058 & 0,060 \\
\hline
\end{tabular}

Note: 1) E1-season 1-September 2008/ E2-station 2-December 2008 / E3-season 3-march 2009;

2) Maximum levels ( $\mu \mathrm{g} . \mathrm{g}^{-1}$ ) - Conama 344/2004: $\mathrm{Cd}-1,2 ; \mathrm{Zn}-150 ; \mathrm{Cu}-34 ; \mathrm{Pb}-46,7 ; \mathrm{Cr}-81 ; \mathrm{Ni}-20,9$. 
Using a tree for visual classification of similarity was constructed a dendogram which showed that despite the variation in metal contents obtained in water and sediment and the physical and chemical variables, there was no significant difference between the three stations sampled for all these variables sampled, except for temperature. The variable temperature was shown to be different between the three sampling stations $(\mathrm{F}=21.76, \mathrm{p}=0.0004)$ with average values of $25.07^{\circ} \mathrm{C}, 26.35^{\circ} \mathrm{C}$ and $24.92^{\circ} \mathrm{C}$ for stations 1,2 and 3 respectively. Sampled stations were significantly different from each other for most of the variables sampled. Variables that showed differences $(\mathrm{p}<0.05)$ in their values to the collection stations were turbidity $(\mathrm{F}=30.21), \mathrm{pH}(\mathrm{F}=48.54), \mathrm{OD}(\mathrm{F}=44.72), \mathrm{Cd}$ water $(\mathrm{F}=20.19), \mathrm{Zn}$ water $(\mathrm{F}=7.38), \mathrm{Cu}$ water $(\mathrm{F}=10.06), \mathrm{Cr}$ water $(\mathrm{F}=17.18)$, Ni water $(\mathrm{F}=5.3), \mathrm{Cd}$ sediment $(\mathrm{F}=7.73), \mathrm{Zn}$ sediment $(\mathrm{F}=9.53)$, $\mathrm{PB}$ sediment $(\mathrm{F}=3.9), \mathrm{Cr}$ sediment $(\mathrm{F}=26.59)$ and $\mathrm{Ni}$ sediment $(\mathrm{F}=7.98)$. The cluster analysis showed that the sampling stations $\mathrm{P} 1$ and $\mathrm{P} 7$ form a single cluster, with a great distance to the other sampling points (Figure 2). Also, a cluster formed for the stations P4 and P5 was observed.

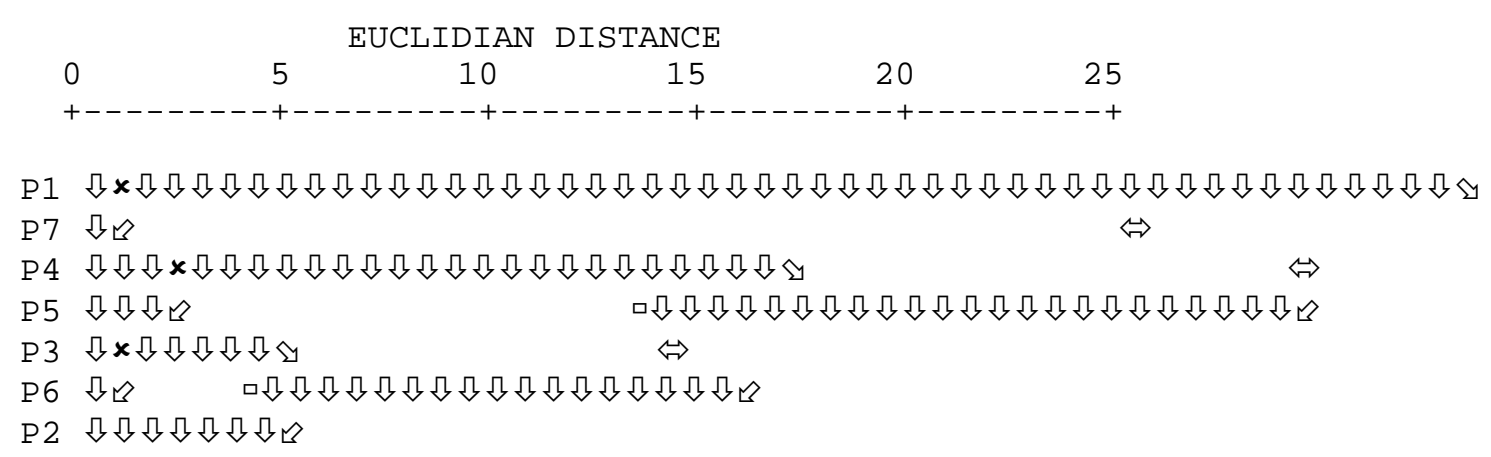

Figure 2. Dendogram for cluster analysis based on water and sediment scores. The dissimilarity is defined by Euclidean distance.

Average concentrations of metals found in birds ranged from 1.45 to 26 times above the limit in the liver and 1.2 to 21 times above the limit in the kidney, based on the maximum allowed value (MAV) established by Decree 55871/65 and Ordinance 685/98. The limits for the metals $\mathrm{Cd}, \mathrm{Pb}, \mathrm{Zn}, \mathrm{Cr}, \mathrm{Cu}$ and $\mathrm{Ni}$ are respectively $1.0,8.0,50.0,0.10,30.0,5.0 \mu \mathrm{g} \cdot \mathrm{g}^{-1}$ (Table 4). Bivariate models were generated as dependent variable the metal content in the liver and kidney of birds (Table 5). Only for the liver significant models were found, no statistical significance was found using the kidney as dependent variable. With the exception of one model, all correlations were found for levels of metals found in water, and for cadmium, a high number of positive correlations between water content and liver of the bird were found.

Table 4. Heavy metal concentrations $\left(\mu \mathrm{g} \cdot \mathrm{g}^{-1}\right)$ in the organs of Nycticorax nycticorax.

\begin{tabular}{crcc}
\hline Element & MV & kidney & liver \\
\hline $\mathrm{Cd}$ & 1,0 & $6,08 \pm 1,41$ & $7,60 \pm 2,66$ \\
$\mathrm{Zn}$ & 50,0 & $76,06 \pm 6,03$ & $60,66 \pm 3,76$ \\
$\mathrm{Cu}$ & 30,0 & $63,27 \pm 12,93$ & $45,32 \pm 2,82$ \\
$\mathrm{~PB}$ & 8,0 & $43,31 \pm 5,99$ & $42,15 \pm 4,60$ \\
$\mathrm{Cr}$ & 0,10 & $2,65 \pm 0,54$ & $2,22 \pm 0,76$ \\
$\mathrm{Ni}$ & 5,0 & $7,39 \pm 1,75$ & $7,75 \pm 0,85$ \\
\hline
\end{tabular}

Note: $M V=$ maximum value. 
FERREIRA, A. P.; HORTA, M. A. P. Trace element residues in water, sediments, and organs of Savacu (Nycticorax nycticorax) from Sepetiba Bay, Rio de Janeiro, Brazil. Ambi-Agua, Taubaté, v. 5, n. 1, p. 17-28, 2010. (doi:10.4136/ambi-agua.116)

Table 5. Significant regression between sampled variables and heavy metal levels in Nycticorax nycticorax.

\begin{tabular}{lccccc}
\hline Dep var & Var. ind & Beta & $\mathbf{R}^{2}$ & $\mathbf{F}$ & $\mathbf{p}$ \\
\hline Cd liver & Cd water E1 & 0.83 & 0.7 & 11.78 & 0.01 \\
& Cd water E3 & 0.83 & 0.69 & 11.36 & 0.01 \\
& Cd sedim. E3 & 0.75 & 0.57 & 6.69 & 0.04 \\
Zn liver & Zn water E3 & 0.84 & 0.71 & 12.25 & 0.01 \\
$\mathrm{Cu}$ liver & Cu water E3 & 0.74 & 0.57 & 6.71 & 0.04 \\
\hline
\end{tabular}

\section{DISCUSSION}

Electric conductivity can provide important information on aquatic ecosystems and on the processes that may be occurring in the drainage basin. Its determination is related to decomposition, dissolved compounds and the presence of ions. Ions most directly responsible are: magnesium, calcium, potassium and sodium. In general, electric conductivity values remained low. For the parameters temperature, $\mathrm{pH}$ and turbidity, the results showed they were within the range recommended, but the results of dissolved oxygen showed some values below the recommended range.

In the systematic release of heavy metals into the environment, as a general analysis, it is known that cadmium is found in natural waters due to industrial discharges, such as electroplating, pigment production, welding, electronics, etc. This metal is also used as component of insecticides. It has no quality, at least known to the present, which makes it beneficial or essential to living beings. It is a metal with high toxic potential and accumulates in aquatic organisms, allowing its entry into the food chain (Savinov et al., 2003). Cadmium was the metal with the highest number of correlations between their levels in water and in the liver of birds. Its high bio-accumulation capacity could be an important factor in explaining this phenomenon. The action on the physiology in the trophic chain is similar to that of nickel, zinc and lead (Monteiro et al., 1998). Cadmium concentrations presented outside the levels in the analysis of water in the dry season at P2, and for all data collected at P3, P4 and P5. However, for the sediment analysis all the stations presented levels above recommended, being more evident in stations P3, P4 and P5.

Zinc, which also showed a positive correlation between its levels in water and liver of birds, is an essential element for growth and it is a common metal in natural waters. Zinc toxic effects are associated with the respiratory system of marine animals and representatives from the top of the food webs. It is widely used in industry, mainly in electroplating, in metal and salt form such as chloride, sulfate, cyanide, etc. This metal can enter the environment through natural processes (leaching of rocks and soils) and anthropogenic, among which stands out the production of iron and steel and domestic sewage (Carvalho et al., 2008). Similarly, lead, whose regression analysis showed a significant positive relationship between its concentrations in water and in the liver of animals, is present in water due to natural leaching of minerals or anthropogenic interference, such as industrial waste, paints, pipes, construction materials (tiles and slabs), impurities of fertilizers, pesticides. Among some potential effects on health, lead poisoning in humans can cause fatigue, irritability, anemia, dizziness, headache, muscle tremors, sensory disturbances, memory loss and reduction of neurophysiological function (Davies et al. 2006; Carvalho et al., 2008).

Although no significant relationship was found between levels in water and liver, copper presented rates in the liver and kidney of birds above recommended levels. This metal, in high concentrations is harmful to health, but in small quantities is beneficial to the human body, catalyzing the assimilation of iron and the synthesis of hemoglobin in the blood, facilitating the cure of anemia (Eisler, 2000). Copper in the environment comes mainly from corrosion of 
wastes in sewage treatment stations, use of compounds as algaecides and water runoff. Groundwater can become contaminated from agricultural uses of copper as fungicide and pesticide in the soil treatment and effluent (Davies et al., 2006, Carvalho et al., 2008).

The aquatic ecosystem has been reported to be the final destination of the heavy metal pollution (Oedekoven et al., 2001). Heavy metal levels in water found in this research were lower than the levels found in the sediment or in the bird organs, what could be related to the higher absorption of these particles in the sediment, while high levels in birds may be linked to bioaccumulation.

\section{CONCLUSION}

The results show significant differences between the sampling stations of this study. Stations P1 and P7 are positioned farther from the input sources of continental waters in Sepetiba Bay, and they were expected to present values of their metals and physical-chemical parameters different from the other sampled stations. This was shown by the cluster analysis, which positioned P1 and P7 separated from other stations. The stations P1 and P7 show a greater flow of incoming tide that provides greater metal dissolution power. Also, the absence of river flow and input of anthropogenic leakage presumably caused a reduction in metal levels that remained detectable under the maximum value allowed by environmental laws (CONAMA). At P6 station, which belongs to Coroa Grande mangrove, higher levels of heavy metals were found, a fact that can be explained by the proximity of river water input which might be carrying some metal compounds, endangering resident fauna by local exposure of the foraging and reproduction area. The other stations (P2, P3, P4 and P5) are located at the entrance of major rivers into the bay, an area formed by municipalities distributed along the main basin. As previously reported, the lack of improved sanitation causes the leaching of significant levels of heavy metals into the Sepetiba Bay, highly impacting the environment. Because these compounds are persistent in physical environment and in the biological systems and the lack of public policies with clear and immediate recovery of marine environments, a silent process of disturbance and reductioning of marine ecosystem complexity can be observed, what becomes a major issue of public health that deserves more attention and improved discussion.

The water system can be divided into three main compartments, the water column, the biotic and abiotic particulate matter and the sediment. It is known that the particulate material contains a chemical that is the result of chemical and physical processes that occur in the water column. As this material is decanted, i.e., with a continuous deposition, it's recorded in sediment changes that water was submitted. This study presents an assessment for these three components, the water column, sediment and a representative from the top of the chain, enabling a better analysis of the levels of heavy metals in Sepetiba Bay. The focus of research in the assessment of heavy metals in birds as a representative of the top of trophic chains shows that despite being sedentary species, the degree of bioaccumulation of metals studied may be reflected also in the migratory species due to exposure. The metal contamination in one area can have harmful effects on an entire region, particularly in areas of active feeding or reproduction, or migration routes and breeding sites.

\section{ACKNOWLEDGEMENTS}

The author Aldo P Ferreira is grateful to CNPq - bolsa de produtividade (306175/2008-8). 


\section{REFERENCES}

Balkis, N.; Cagatay, M. N. Factors controlling metal distributions in the surface sediments of the Erdek Bay, Sea of Marmara, Turkey. Environment International, v. 27, p. 1-13, 2001.

Bonai, N. C.; Souza-Franco, G. M.; Fogolari, O.; Mocelin, D. J. C.; Dal Magro, J. Distribution of metals in the sediment of the Itá Reservoir, Brazil. Acta Limnologica Brasiliensis, v. 21, n. 2, p. 245-250, 2009.

Bost, C. A.; Lemaho, Y. Seabirds as bio-indicators of changing marine ecosystems - new perspectives. Acta Oecologica, v. 14, n. 3, p. 463-470, 1993.

BRANCO, J. O.; FRACASSO, H. A. A. Reprodução de Nycticorax nycticorax (Linnaeus) no litoral de Santa Catarina, Brasil. Revista Brasileira de Zoologia, v. 22, n. 2, p. 424429, 2005.

BRASIL. Resolução CONAMA 344, de 25 de março de 2004. Estabelece as diretrizes gerais e os procedimentos mínimos para a avaliação do material a ser dragado em águas jurisdicionais brasileiras, e dá outras providências. Diário Oficial da União, Brasília, DF, n. 87, 07 maio 2004. Seção 1, p. 56-57.

BRASIL. Resolução CONAMA 357, de 17 de março de 2005. Dispõe sobre a classificação dos corpos d'água e diretrizes ambientais para o seu enquadramento, bem como estabelece as condições e padrões de lançamento de efluentes, e dá outras providências. Diário Oficial da União, Brasília, DF, n. 53, 18 mar. 2005. Seção 1, p. 58-63.

CARVALHO, C. E. V.; DI BENEDITTO, A. P. M.; SOUZA, C. M. M.; RAMOS, R. M. A.; REZENDE, C. E. Heavy metal distribution in two cetacean species from Rio de Janeiro State, south-eastern Brazil. Journal of the Marine Biological Association of the United Kingdom, v. 88, n. 6, p. 1117-1120, 2008.

COIMBRA, A. G. Distribuição de metais pesados em moluscos e sedimentos nos manguezais de Coroa Grande e da Enseada das Garças, Baía de Sepetiba, RJ. 2003. 72f. Dissertação (Mestrado em Geoquímica Ambiental) Universidade Federal Fluminense, Rio de Janeiro, 2003.

COPELAND, G.; MONTEIRO, T.; COUCH, S.; BORTHWICK, A. Water quality in Sepetiba Bay, Brazil. Marine Environmental Research, v. 55, p. 385-408, 2003.

CUNHA, C. L. N.; ROSMAN, P. C. C.; FERREIRA, A. P.; MONTEIRO, T. C. N. Hydrodynamics and water quality models applied to Sepetiba Bay. Continental Shelf Research, v. 26, p. 1940 - 1953, 2006.

DALE, V. H.; BEYELER, S. C. Challenges in the development and use of ecological indicators. Ecological Indicators, v. 1, p. 3-10, 2001.

DAVIES, O. A.; ALLISON, M. E.; UYI, H. S. Bioaccumulation of heavy metals in water, sediment and periwinkle (Tympanotonus fuscatus var radula) from the Elechi Creek, Niger Delta. African Journal of Biotechnology, v. 5, n. 10, p. 968-973, 2006.

DIAMOND, A. W.; DEVLIN, C. M. Seabirds as indicators of changes in marine ecosystems: ecological monitoring on Machias Seal Island. Environmental Monitoring and Assessment, v. 88, p. 153-175, 2003. 
EISLER, R. Handbook of chemical risk assessment: health hazards to humans, plants and animals. Boca Raton: Lewis, 2000. 738 p.

FÖRSTNER, U. E.; WITTMANN, G. T. W. Metal pollution in the aquatic environment. Berlin: Spring-Verlag, 1981. 486p.

FURNESS, R. W.; CAMPHUYSEN, C. J. Seabirds as monitors of the marine environment. Ices Journal of Marine Science, v. 54, n. 4, p. 726-737, 1997.

JESUS, H. C.; COSTA, E. A.; MENDONCA, A. S. F.; ZANDONADE, E. Distribuição de metais pesados em sedimentos do sistema estuarino da Ilha de Vitória-ES. Química Nova, v. 27, n. 3, p. 378-386, 2004.

GADD, G. M. Interactions of fungi with toxic metals. New Phytologist, v. 124, p. 25-60, 1993.

LACERDA, L. D.; MOLISANI, M. M. Three decades of $\mathrm{Cd}$ and $\mathrm{Zn}$ contamination in Sepetiba Bay, SE Brazil: evidence from the mangrove oyster Crassostraea rhizophorae. Marine Pollution Bulletin, v. 52, n. 8, p. 974-977, 2006.

MACHADO, J. C. V. Estudo do grau de contaminação por hidrocarbonetos nos sedimentos da Baía de Todos os Santos. 1996. 136f. Dissertação (Mestrado em Química Analítica) - Universidade Federal da Bahia, Salvador, 1996.

MONTEIRO, L. R.; GRANADEIRO, J. P.; FURNESS, R. W. Relationship between mercury levels and diet in Azores seabirds. Marine Ecology Progress Series, v. 166, p. 259265, 1998.

MORAES, D. S. L.; JORDAO, B. Q. Degradação de recursos hídricos e seus efeitos sobre a saúde humana. Revista de Saúde Pública, v. 36, n. 3, p. 370-374, 2002.

OEDEKOVEN, C. S.; AINLEY, D. G.; SPEAR, L. B. Variable responses of seabirds to change in marine climate: California current, 1985-1994. Marine Ecology-Progress Series, v. 212, p. 265-281, 2001.

PEREIRA, G. C.; EBECKEN, N. F. F. Knowledge discovering for coastal waters classification. Expert Systems with Applications, v. 36, n. 4, p. 8604 - 8609, 2009.

ROSS, P. S.; BIRNBAUM, L. S. Integrated human and ecological risk assessment: a case study of persistent organic pollutants (Pops) in humans and wildlife. Human and Ecological Risk Assessment, v. 9, n. 1, p. 303-324, 2003.

SAVINOV, V. M.; GABRIELSEN, G. W.; SAVINOVA, T. N. Cadmium, zinc, copper, arsenic, selenium and mercury in seabirds from the Barents Sea: levels, inter-specific and geographical differences. The Science of the Total Environment, v. 306, n 1/3, p. 133-158, 2003.

SCHMITT-JANSEN, M.; VEIT, U.; DUDEL, G.; ALTENBURGER, R. An ecological perspective in aquatic ecotoxicology: Approaches and challenges. Basic and Applied Ecology, v. 9, n. 4, p. 337-345, 2008.

SEEBAUGH, D. R.; GOTO, D.; WALLACE, W. G. Bioenhancement of cadmium transfer along a multi-level food chain. Marine Environmental Research, v. 59, n. 5, p. 473491, 2005. 
FERREIRA, A. P.; HORTA, M. A. P. Trace element residues in water, sediments, and organs of Savacu (Nycticorax nycticorax) from Sepetiba Bay, Rio de Janeiro, Brazil. Ambi-Agua, Taubaté, v. 5, n. 1, p. 17-28, 2010. (doi:10.4136/ambi-agua.116)

KAMALA-KANNAN, S.; BATVARI, B. P. D.; LEE, K. J.; KANNAN, N.; KRISHNAMOORTHY, R.; SHANTHI, K. et al. Assessment of heavy metals (Cd, Cr and $\mathrm{Pb}$ ) in water, sediment and seaweed (Ulva lactuca) in the Pulicat Lake, South East India. Chemosphere, v. 71, n. 7, p. 1233-1240, 2008.

VAN STRIEN, A. J. From monitoring data to policy-relevant summary statistics. Bird Numbers 1998. Vogelwelt, v. 120, p. 67-71, 1999.

WANLESS, S.; HARRIS, M. P.; REDMAN, P.; SPEAKMAN, J. R. Low energy values of fish as a probable cause of a major seabird breeding failure in the North Sea. Marine Ecology-Progress Series, v. 294, p. 1-8, 2005. 